\title{
TEACHING ENGLISH WITH INSTA.LING ONLINE PLATFORM: CASE STUDY IN HIGHER EDUCATION LEVEL
}

\begin{abstract}
The paper presents a study about using Insta.Ling e-learning platform in university teaching process of English language for Biology students. The aim of this study is to estimate its effectiveness and the correlation between the number of repetitions and the number of words memorized. The total number of students involved in this research is 129 ( 6 student groups and in 3 academic years). They are all students of Cardinal Stefan Wyszynski University, Warsaw. The results allow to assume that Insta.Ling environment is an effective way to learn new vocabulary and regular sessions positively affect the number of vocabulary memorized.
\end{abstract}

Keywords: e-learning; information and communication technology (ICT); virtual learning environments (VLE); higher education; English language teaching.

\section{Introduction}

An effective, high-quality education system is one of the central values in society worldwide (ITU, 2018). Naturally, the development of the Internet and its applications determined an increase of its role in learning process. Many studies indicate that the use of it develops and improves students digital competences (EU, 2012; McKnight et al., 2016) or foreign language skills (EU 2017). Access to technology is an important factor, however, it is crucial to move the focus beyond the technology itself, to how technology supports teaching and learning (McKnight et al., 2016). Another reason why educational institutions have an increasing need to use virtual learning environments is its wide implementation in the society (ITU, 2018) but also it brings positive effects on students' knowledge (Mumtaz, 2000; Haßler, 2016). What is more, general ICT skills are needed at the market and the educational institutions must provide future workers equipped with such competences (Fraillon et al., 2018). Therefore, it became a formal key element on the agenda of scholars, practitioners and policymakers worldwide. 
E-learning is becoming a popular and effective learning approach within greater academic settings due to high use of web systems in learning itself (Cabero-Almenara et al., 2016; Noesgaard \& Ørngreen, 2015). It involves utilization of information and communication technology (ICT) to improve students' academic achievement. Research comparing the effects of digital learning to traditional classroom instruction has yet to show consistent and, significant advantages for digital learning (Brown \& Park, 2016; Petko et al., 2017). Some studies report that digital classrooms outperform traditional classrooms also academic (Holcomb, 2009; Mothibi, 2015; Pai, 2013; Suhr et al., 2010), while others report no difference or the reverse (Cuban, 2006; Penuel, 2006; Yi Ni, 2013). Many authors note that the full implementation is a complex process and should be considered multidirectionally (Baller et al., 2016). There is also the need to bring (in case studies) more positive results of ICT implementation into the teaching process (Katherine et al., 2016).

The first important goal in this case study was to investigate the level of effectiveness measured as the number of memorized words of the Insta.Ling platform in English language (EL) teaching and learning (T\&L) to students of Biology at the university level. Students were expected to work every day form Monday to Friday, three times a day. Here the author intended to measure in this intensive course how many words students were able to memorize in one term and what was the maximum or average number of them. Another goal was to find and set the correlation between the number of repetitions (regular practice-RP) and the number of vocabulary learnt (words memorized - WM). Furthermore, the study tried to find out what is the effectiveness of the platform, if the students make lower number of repetitions, asking e.g. is working twice a day or once a day the same enough (is it equally effective) as three times a day, to memorize all words given by the teacher for regular practice? This research was done in the groups of students attending basic and advanced courses. The total number of students involved in this research is 129, in 6 student groups, in 3 academic years. The assessment of the supporting role of Insta.Ling platform (for teachers) in EL T\&L was also measured as well as the students' attitude towards this platform. Another aim of the research presented in this paper is to check the effectiveness of the platform (and the course) in general increase in English language knowledge in Biology. Here the students EL level was measured at the beginning and at the end of the course.

\section{Methodology}

The research was divided into several categories according to the goals. The first part is concerned with the effectiveness of the platform among students taking part in English course for Biology students at the basic level in 2017/2018. Another part is dedicated to students of 3 academic years, taking part in the advanced level from $2016 / 2017$ to $2018 / 2019$. The last part collected students' opinions and was provided in two academic years $(2016 / 2017,2017 / 2018)$ among students at basic level. Each 
group the research has undergone is described in each subtitle. Students come from the Cardinal Stefan Wyszyński University, Faculty of Biology and Environmental Sciences. They all practiced English on Insta.Ling platform throughout one term having one 9o-minute meeting once a week. The main differences existed between groups (basic or advanced level) were based on the exact vocabulary taught, the number of it and the number of repetitions. It is mainly because of differences in English language level between groups and students' interests.

Students practicing language learning on Insta.Ling platform and providing regular exercises had to fill in a gap in the sentence with the correct word. The Polish translation for these words were given. The most of the words are also pronounced, what is additional value. The platform delivers the possibility to teachers to select exact words for practice and even add their own words and sentences to the platform's database. Therefore, the students learn the only words which are in the curriculum of the course. The teacher can also set up the number of words repeated in one practice (session). Teacher can also check how many times students visited the platform, how many repetitions were provided by students, how much time students spent on the practice or which words were the most difficult for them. The Insta.Ling platform is available free of charge and the developer assures that all students can work at an individual pace according to their abilities. This mechanism is described in the previous investigation (Baranowski, 2018), but the real algorithm is a company's secret. The most important thing is the fact, that students revise only words, which are hard to remember because, the platform's mechanism detects the students' mistakes. So, the students do not practice the words which are well memorized by them and it is why the seems to be effective and respond to individual students' needs. The average time spent in one practice (session) is less than 5 minutes, if there is a limit set up for 20 sentences. The platform is very handy and enables students to practice English words with the use of the smartphone, tablet or the computer.

BASIC LEVEL 2017/2018. The investigation was carried out in the second term in the group of the first-year students during the English language for Biology students (basic level). The course was based on interactive and communicative speaking exercises during the meetings as well as reading several related pages at home, doing online exercises and working on the Insta.Ling platform. Students were expected to work every day from Monday to Friday, three times a day. The number of revised words during each session amounted to a maximum of 20. The group of first-year students consisted of 41 participants. 6 people who did not finish the course due to the fact they did not keep working on the platform were removed from the analysis.

ADVANCED LEVEL 2016/2017, 2017/2018, 2018/2019. The next group are the students taking part in English for Biology students course at advanced level. The number of students in each year differs and there are 10 students in 2016/2017 group, 16 students in 2017/2018 group and 22 students in 2018/2019 group. 
Students were supposed to work every day form Monday to Friday, twice a day. The number of revised words during each practice (session) amounted up to 20.

ADVANCED LEVEL $2017 / 2018$ pre-post. In this group of 20 students at the beginning of the term, during the first meeting the knowledge test was provided. It consisted of 3 types of tasks, 10 sentences each. In the first type there were gaps in the sentences and the students had to fill them in with a proper word. An additional (supporting) word was given in Polish. The second type of the task consisted of sentences with gaps, but students were given 15 words and they could choose 10 of them. The third part was the most difficult with no hints provided. During the term students also repeated the practice on platform twice a day, 5 times a week. But in this group the words students were practicing on the platform did not appear at the beginning and at the final tests but they were in texts, presentations or on-line exercises. This was due to the aim concentrated on checking the general influence of the course and platform on specific English language competence. The data was collected through tests prepared as online forms ${ }^{1}$.

QUESTIONNAIRES 2016/2017, 2017/2018. At the end of the term Biology students of basic level were asked 11 questions in the online questionnaire ${ }^{2}$. Altogether, in two academic years there were 51 responses. They were provided in two groups of students learning on the Insta.Ling platform.

\section{Results}

The results of the research are presented according to the aims and methodology. Therefore this part is divided into several subtitles and described in details. Beside the main analyses are presented in the figures, some of them are just presented and discussed.

BASIC LEVEL 2017/2018. The figure 1 indicates that 12 students were able to memorize more than 350 words during one term but the following 23 of them memorized more than 450 . The average number of systematic practice (RP the number of all repetitions on platform) in that 23 students group is 219, working days (WD) 77 and memorized words (WM) 516. And in 12 students group the average numbers are: 139 (RP), 51 (WD) 374 (RW). It is worth mentioning that the required (obligatory) number of working days was 76 and this was the maximum number of days excluding weekends and holidays during the term. The maximum number of systematic practice was 228 calculated as 3 practices a day, averaging at 219. Pearson correlation coefficient between RP and RW is 0.86 and between WD and RW is 0.85 . This positive relation indicates the strong relationship between the number of repetitions and the words memorized. The general relationship

1 Baranowski A. Final Test Biology in English. Available at: http://bit.ly/fp2019-1-baranowski1.

2 Baranowski A. Ankieta ewaluacyjna - jezzk angielski podstawowy. Available at: http://bit.ly/ fp2019-1-baranowski2. 


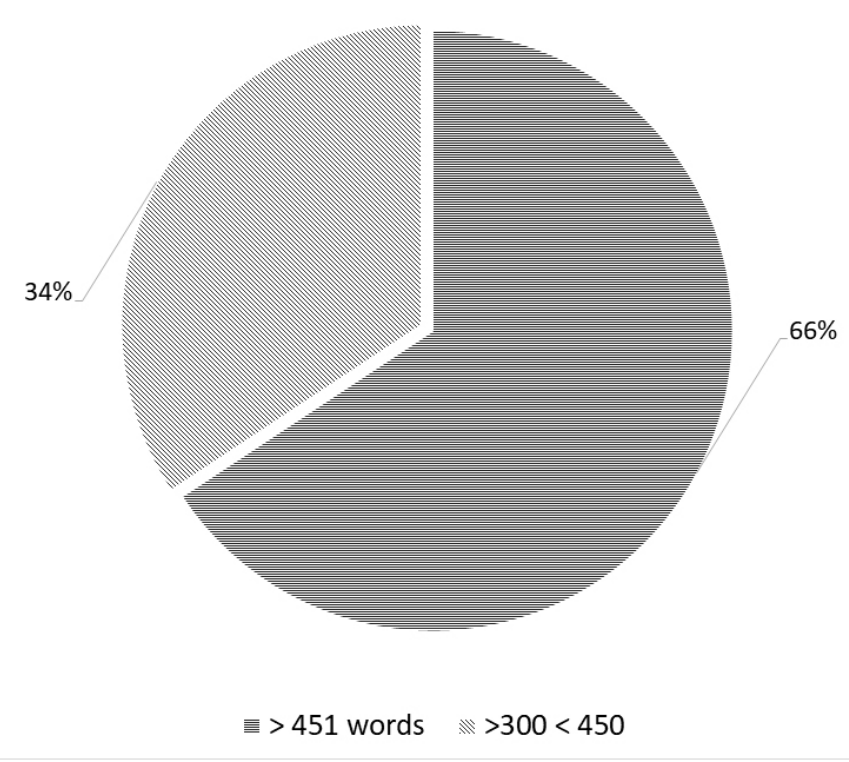

Figure 1. The percentage of students who learnt vocabulary in two categories

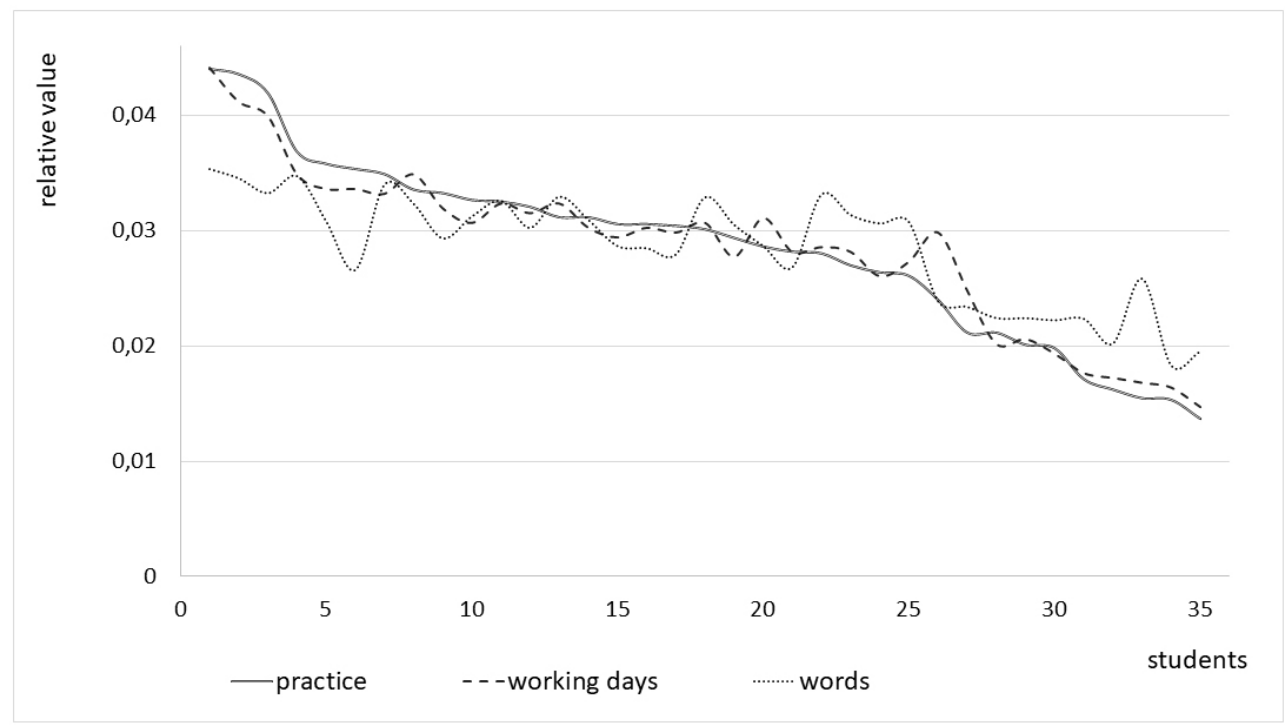

Figure 2. The relations between the number of all systematic practice on platform, working days and number of words memorized.

between RP, WD and RW is shown on the figure 2. R Square for RP and WM (R2) shown in figure 3 equals 0.7399 . It means that $74.0 \%$ of the variance of $\mathrm{WM}(\mathrm{Y})$ is explained by RP $(\mathrm{X})$. Overall regression is right tailed, $\mathrm{F}(1,33)=93.8619, \mathrm{p}$-value $=$ 3.557e-11. Since p-value $<\alpha(0.05)$.

The linear regression model, provides a better fit than the model without the independent variable. Residual normality linear regression assumes normality 


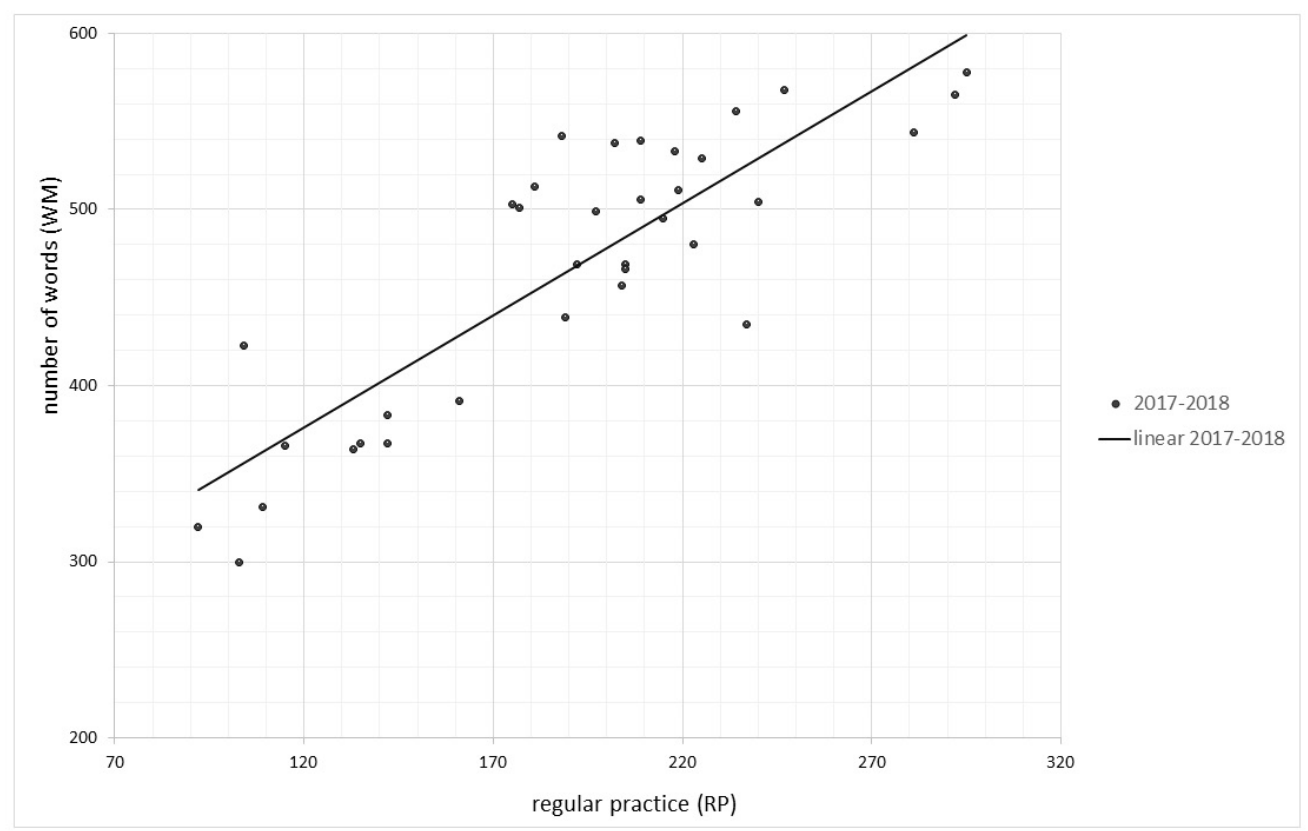

Figure 3. The linear regression $\mathrm{Y}=1.2718 \mathrm{X}+223.8925$.

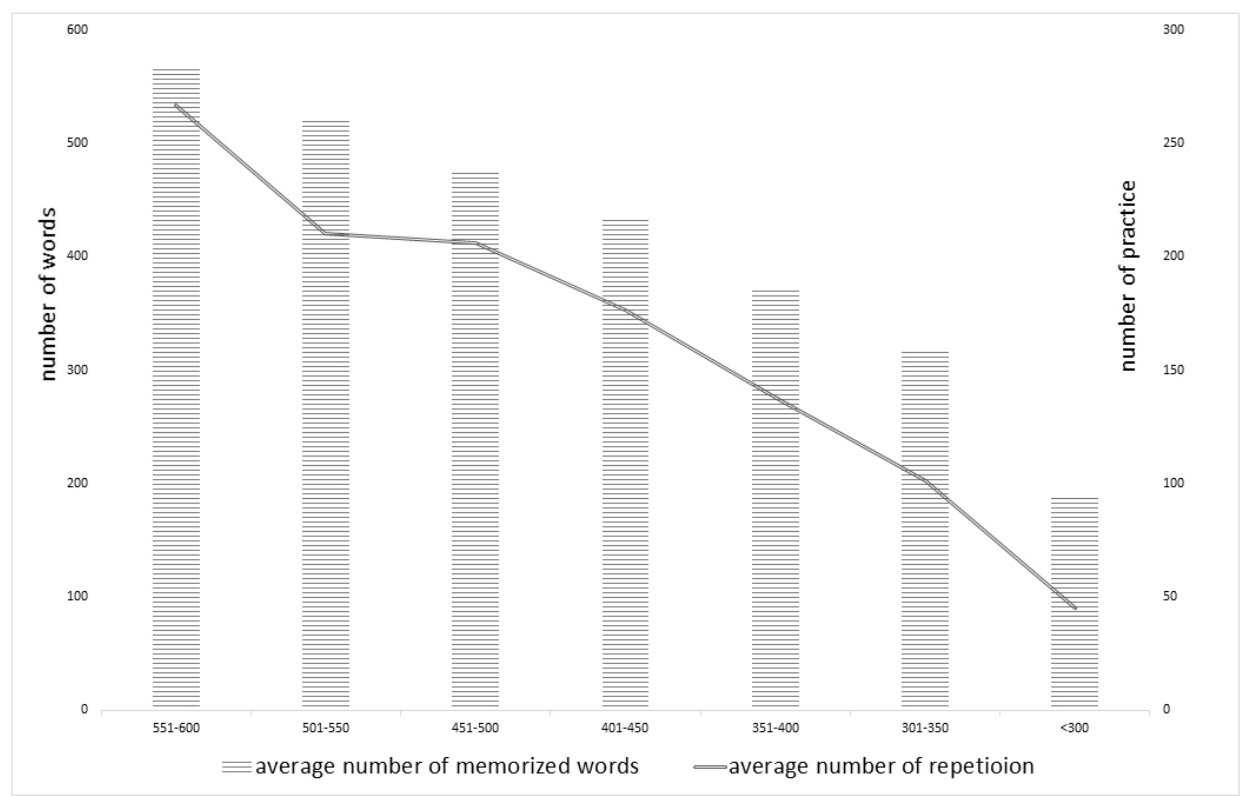

Figure 4. The relation between the number of all systematic practice and number of words memorized separated into 7 categories.

for the residual errors. Shapiro p-value equals 0.06619 and it is assumed that the data is normally distributed.

The figure 4 presents the very strong relationship (Pearson correlation - 0,9897) between the average number of RP and WM. What is more, R Square for RP and WM equals 0.9795 . It means that $98.0 \%$ of the variance of WM (Y) is explained by RP (X). 


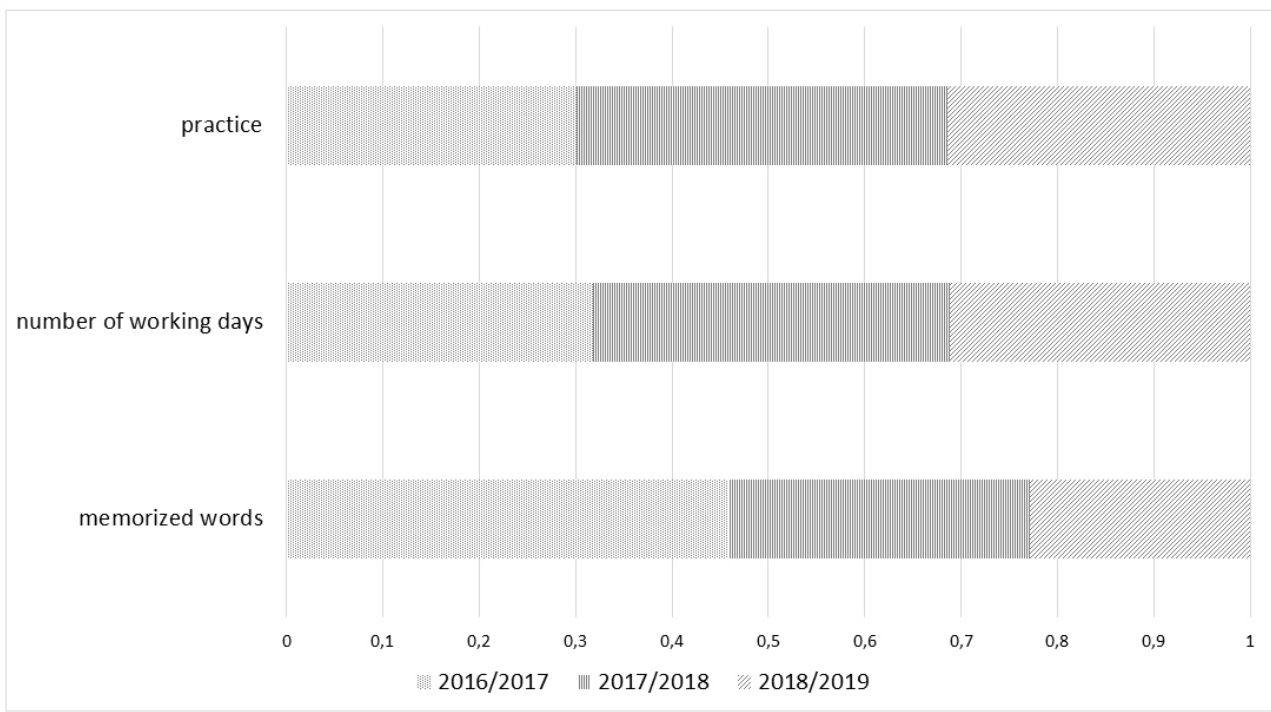

Figure 5. The relation among the practice, number of working days and number of words memorized between three academic groups taking an advanced English course.

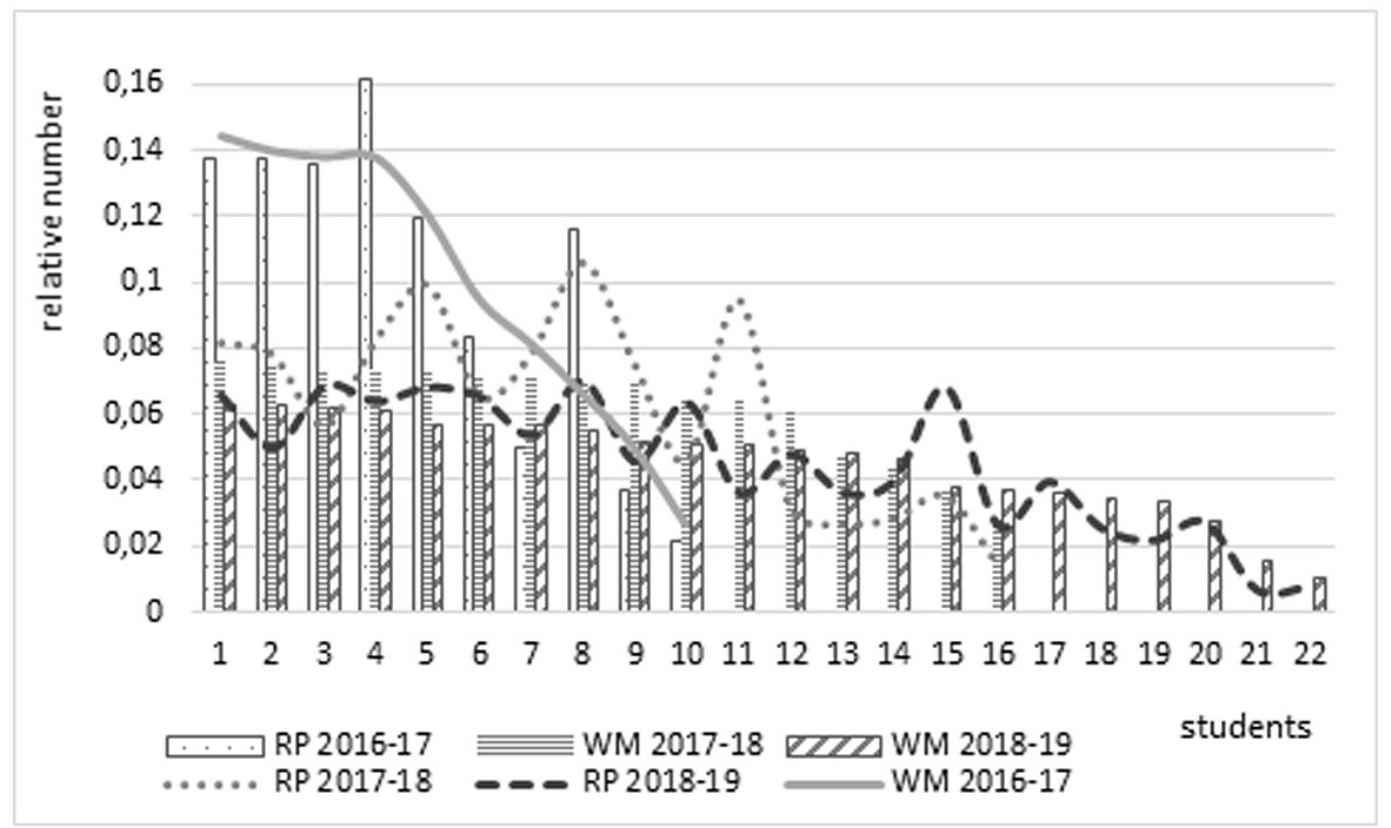

Figure 6. The relation between the RP and number of WM in three academic groups of advanced English level group.

ADVANCED LEVEL 2016/2017, 2017/2018, 2018/2019. The figure 5 presents the summary of relation among the three main factors RP, WM and WD in the three academic years. The following figures are shown as a summary considering relative numbers because of the unequal number of students' groups. Here in figure 5 the dynamic changes are seen between groups and their individual character is presented in figure 6. 


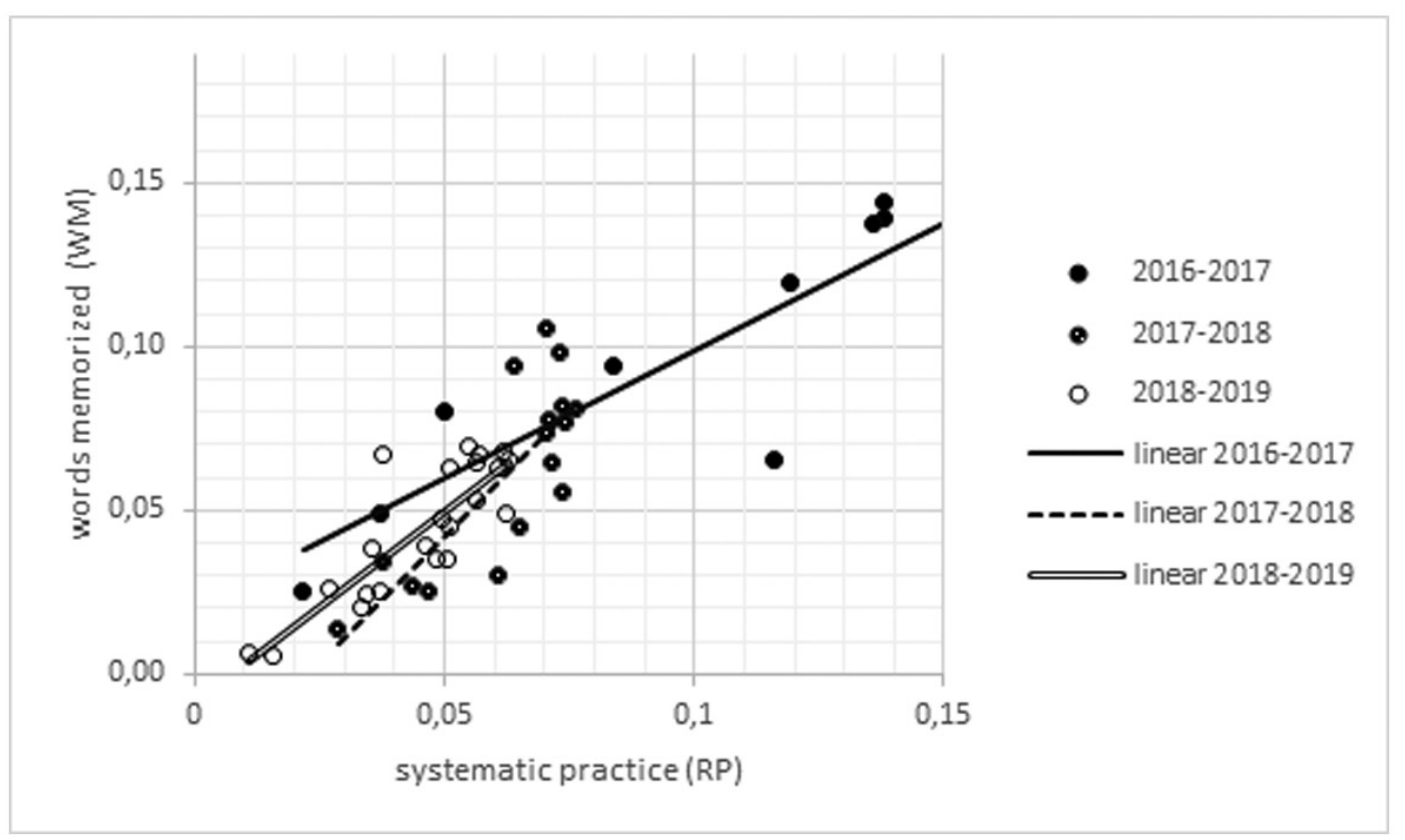

Figure 7. The linear regression between RP and WM; 2016-2017 y = 0,781x + 0,0219; 2017$2018 y=1,5564 x-0,0348 ; 2018-2019 y=1,1567 x-0,0071$.

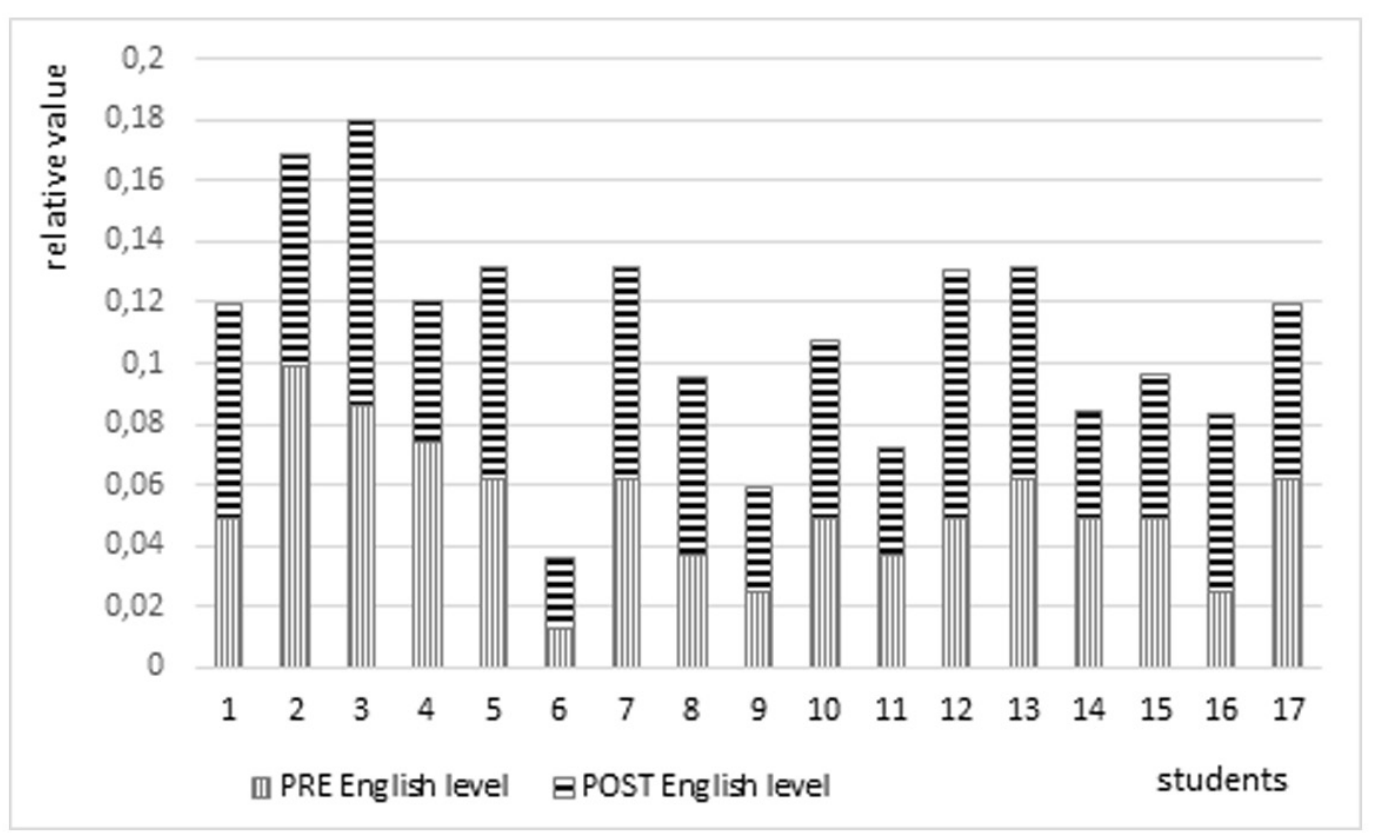

Figure 8. The results of the pre-test and post-test.

The calculated Pearson correlation coefficient (PCC) is strong in every group in relation between systematic practice (RP) and words memorized (WM) as well as regression $\left(\mathrm{R}^{2}\right)$ and comes to in 2016-17, PCC - 0.8913; $\mathrm{R}^{2}-0.7945$, in 2017-18, PCC - 0.8002; $\mathrm{R}^{2}-0.6404$ and in 2018-19, PCC - 0.8419; $\mathrm{R}^{2}-0.7088$. 


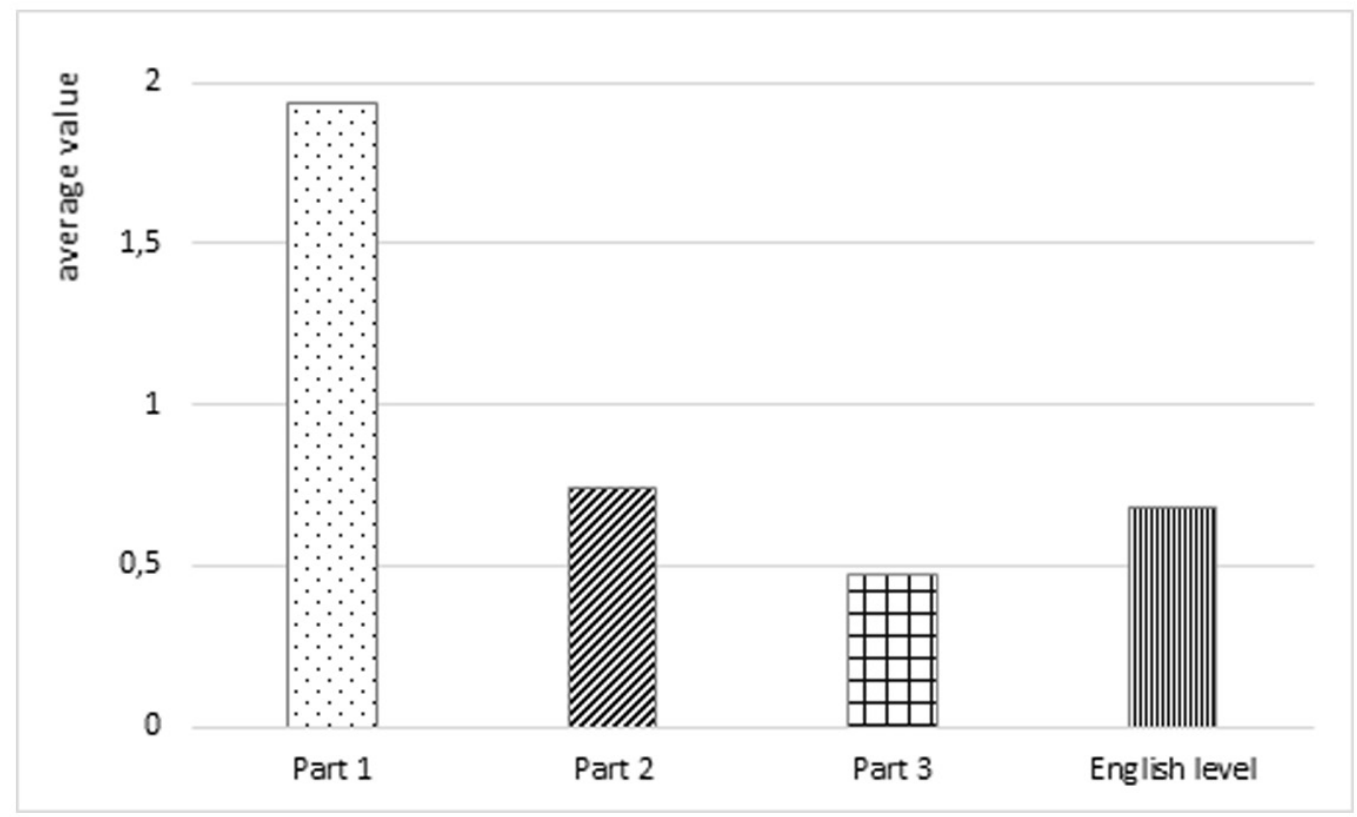

Figure 9. The average differences between the results of the pre-test and post-test.

ADVANCED LEVEL 2017/2018 pre-post. The analysis below is based on the group of 17 students. The figure 8 shows up that every student increased its language competence (statistical significance t-test $=0.0274$ ) during one term course and figure 9 indicates that the highest rise involved the simplest task concerned with translation (statistical significance $t$-test $=0.0021$ ). Here the figure 9 revels also the increase of language competence (English level) in student's opinion.

The gain between the results reached at the beginning and at the end of the term.

QUESTIONNAIRES 2016/2017, 2017/2018. In two academic groups (in two years) consisted of 51 students at the end of the course the anonymous questionnaire 3 was provided. It consisted of 11 question e.g. collecting the students' opinion about the effectiveness of Insta.Ling platform. Figure 10 reveals, that among many forms and methods of working during the class, the most feature is Insta.Ling platform and kahoot game. Almost every 3 of 4 students indicated clearly these methods as the most influential having the possibility to choose only 3 of all methods. In Figure 11 the students' answers show that $76 \%$ of them finds the platform's helpful in the 3 highest categories. According to the kahoot game $69 \%$ of students similarly finds that method very positively. However, students also point on the methods they would not like to take part in the next years (data analysed but not published fully here) as drawing or listening and writing. Every third student matches this method.

3 Baranowski A. Questionnaire evaluation - basic level. Available at: http://bit.ly/fp2o19-1 -baranowski2 


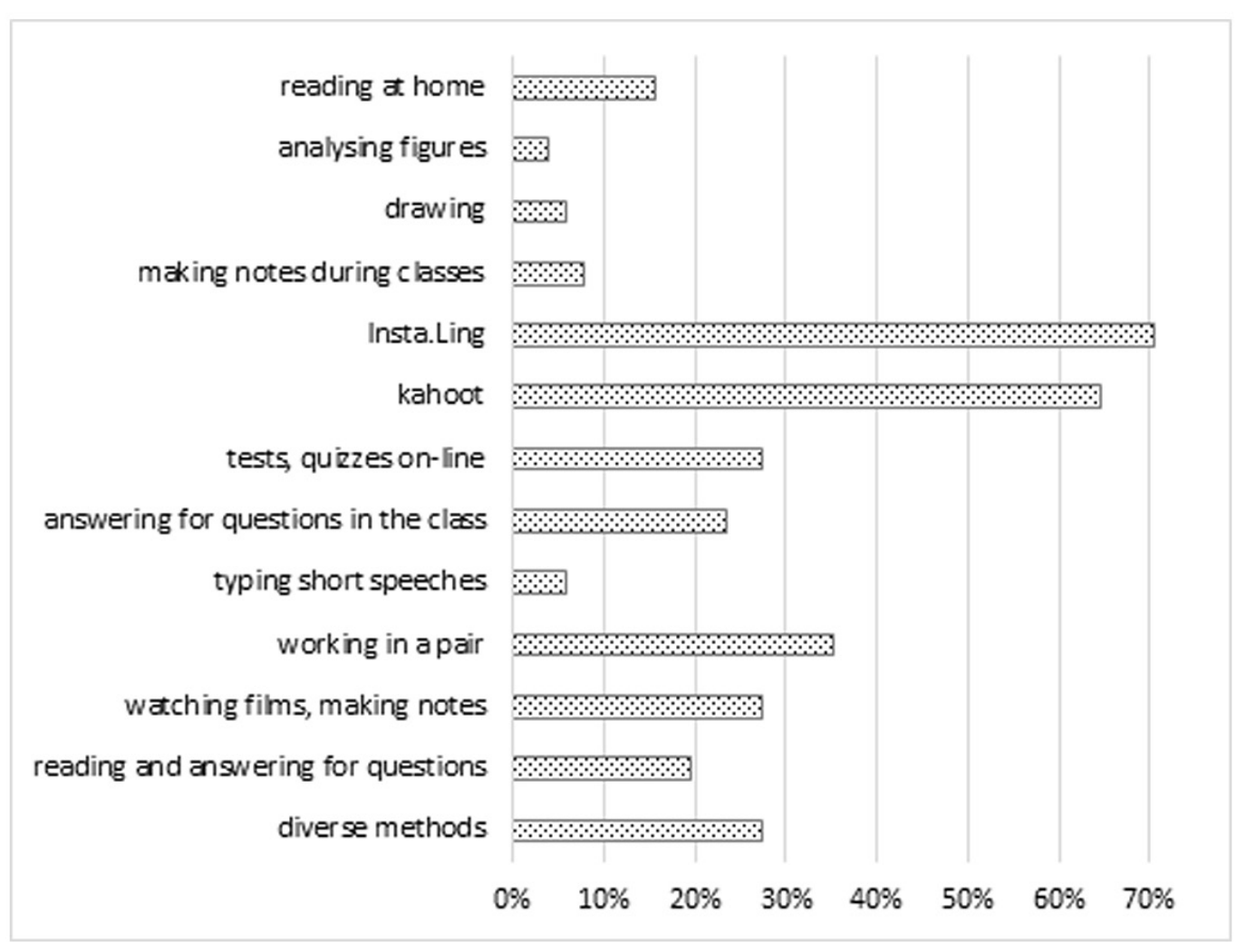

Figure 10. Students answer for the question "Which activities do you consider the most useful in language learning - choose 3 most important".

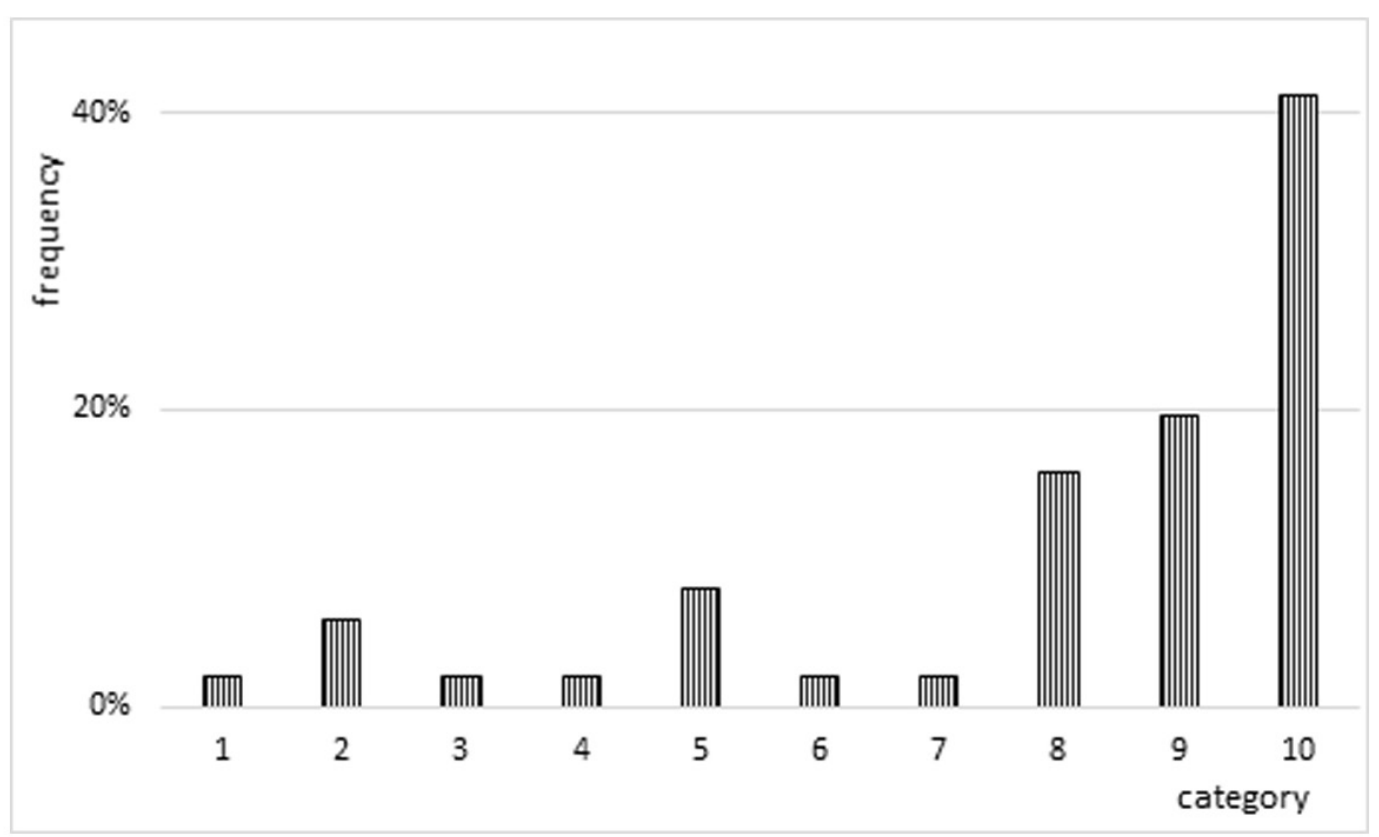

Figure 11. Students' answers to the question "How helpful is the Insta.Ling platform in language learning? (1 - strongly disagree, 10 - strongly agree)". 


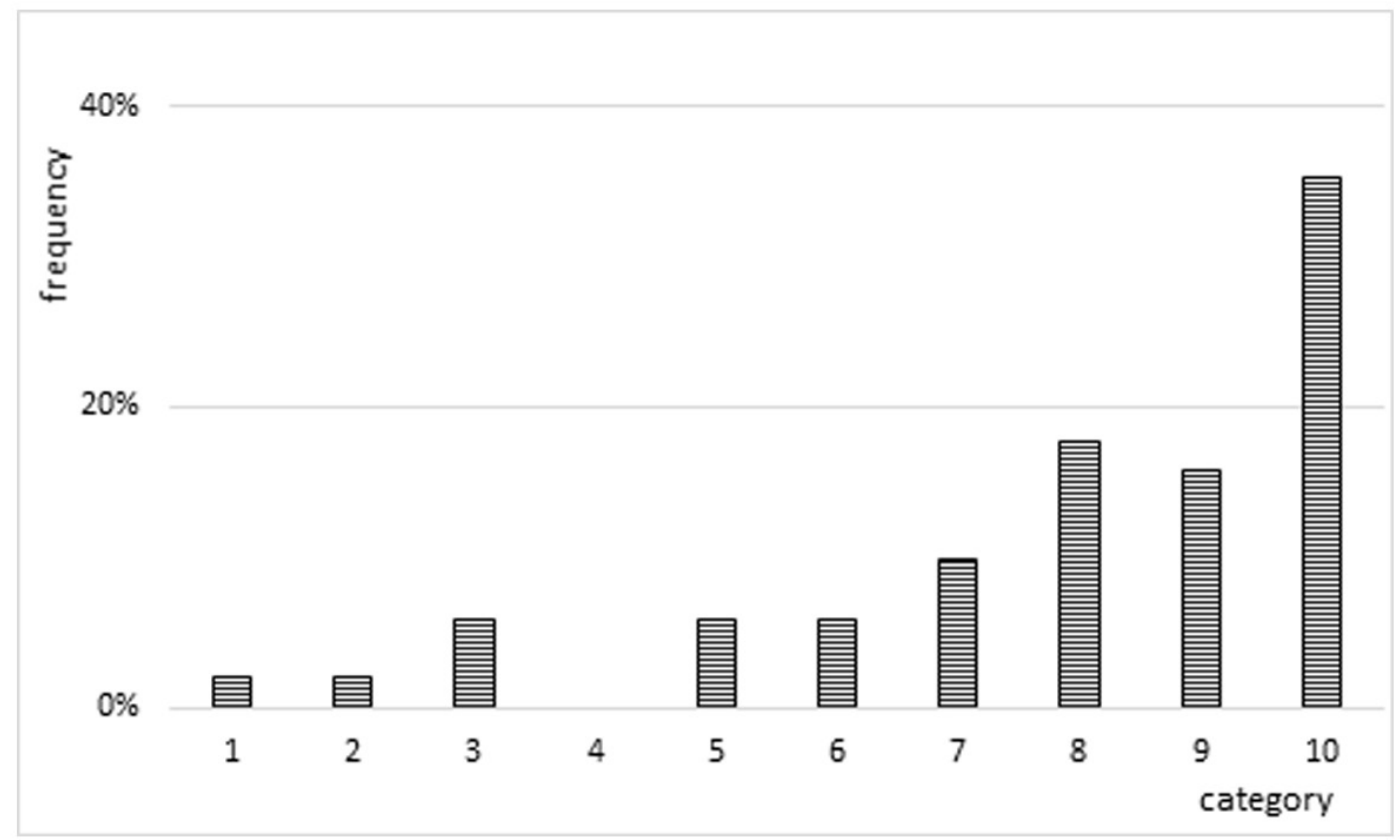

Figure 12. Students' answers to the question "How helpful is the Insta.Ling platform in language learning (1 - strongly disagree, 10 - strongly agree)".

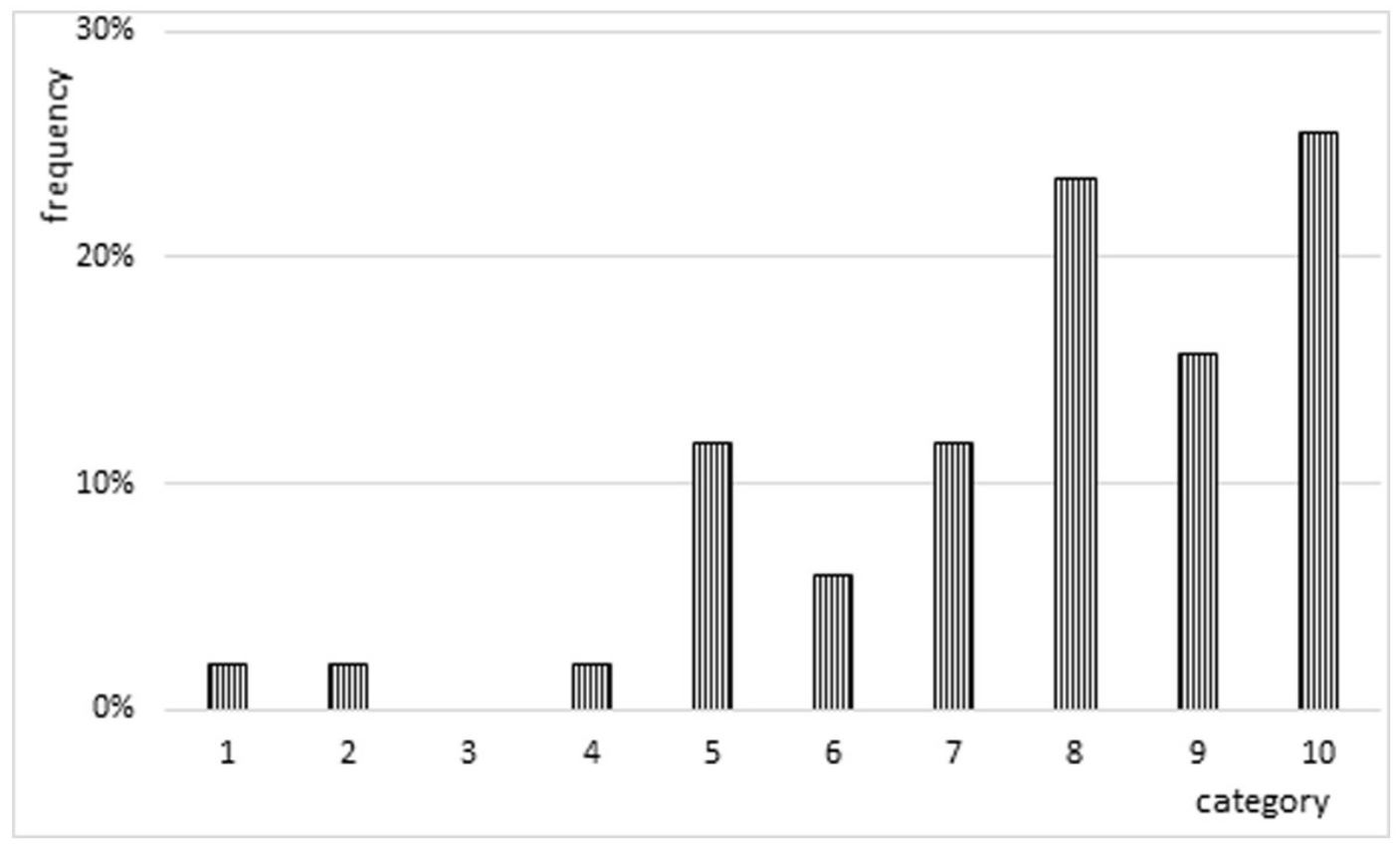

Figure 13. Students answer for the question "How helpful is the Insta.Ling platform in in language learning (1 - strongly disagree, 10 - strongly agree)". 


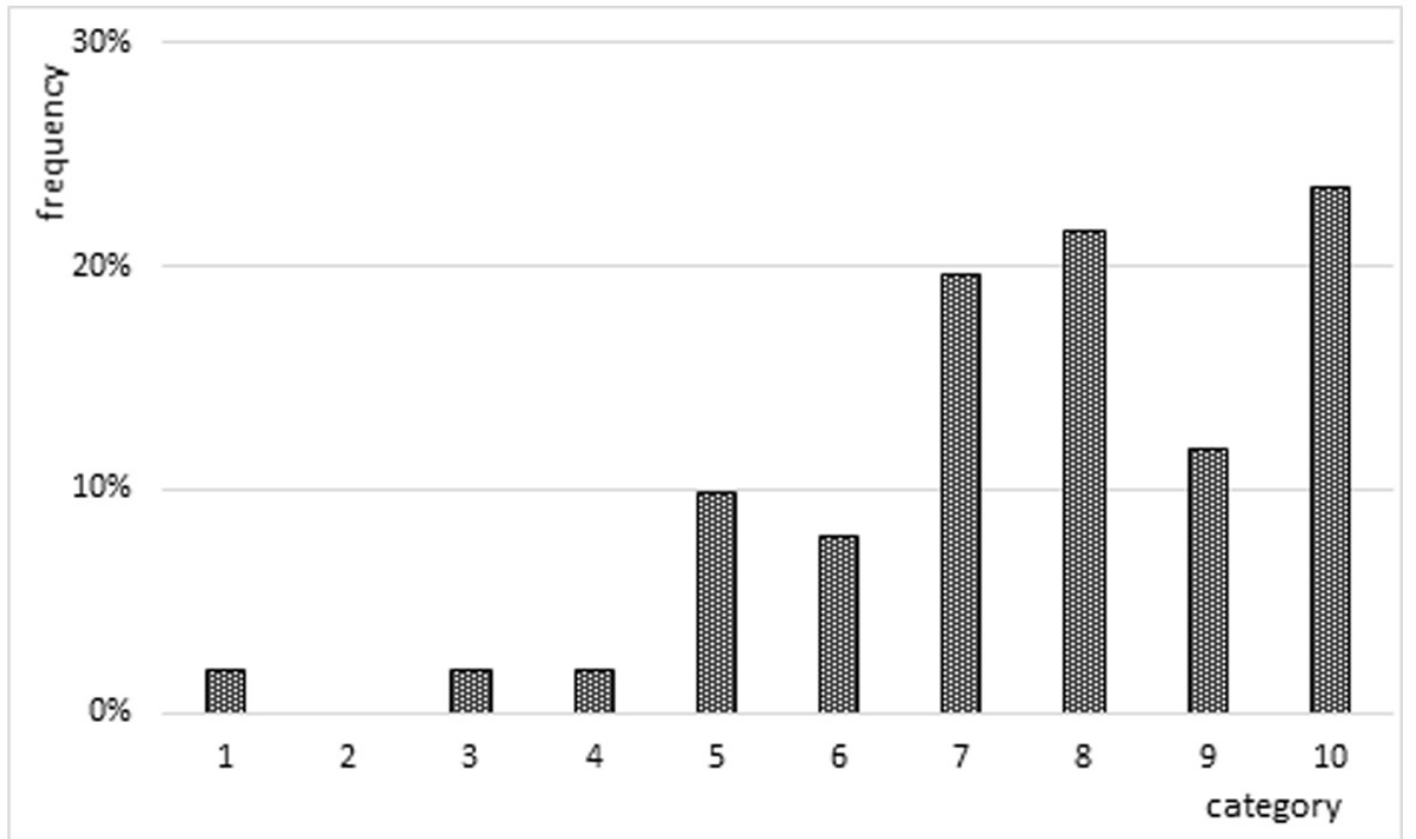

Figure 14. Students' answers to the question "How helpful are the meetings in the course in language learning ( 1 - strongly disagree, 10 - strongly agree)".

The figure 13 explicitly reveals that students' opinion on the Insta.Ling platform is positive and they find it as an effective way of English vocabulary learning. Essentially only 3 students have negative opinion on its efficacy, while 48 of them possess a rather positive opinion towards its effectiveness (categories 5-7; 15 students) or consider it highly effective (categories 8-10; 33 students). Generally speaking the students also find the course positive (figure 14) and the dependence of their final mark on their individual engagement (figure 15). According to 2 students their language competences did not rise after the course, but most of them declared the opposite opinion. 22 students declared their language competences rather increased (categories 5-7) or highly increased (categories 8-10; 26 students) (figure 16). What is more (data gathered in the online questionnaire) $56 \%$ of students indicate that the course should last longer than one term. $30 \%$ of the respondents would prefer a 2 -term course, while $24 \%$ would require 3 or more terms. For $44 \%$ of students a one-term course is sufficient.

The anonymous questionnaire included also open questions. The students' opinions on the Insta.Ling platform are presented below:

Student 1 "Insta.Ling platform is a genius idea. It facilitates memorizing vocabulary and motivates for a regular repetition."

Student 2 "Insta.Ling platform should be continued as it is."

Student 3 "I am positively surprised by the Insta.Ling platform, it was really nice learning in this environment [...]. Obviously, the more frequently the revision is done the better, but twice a day and 5 times a week is quite tiring. Generally, the course was exhausting but I have learnt a lot." 


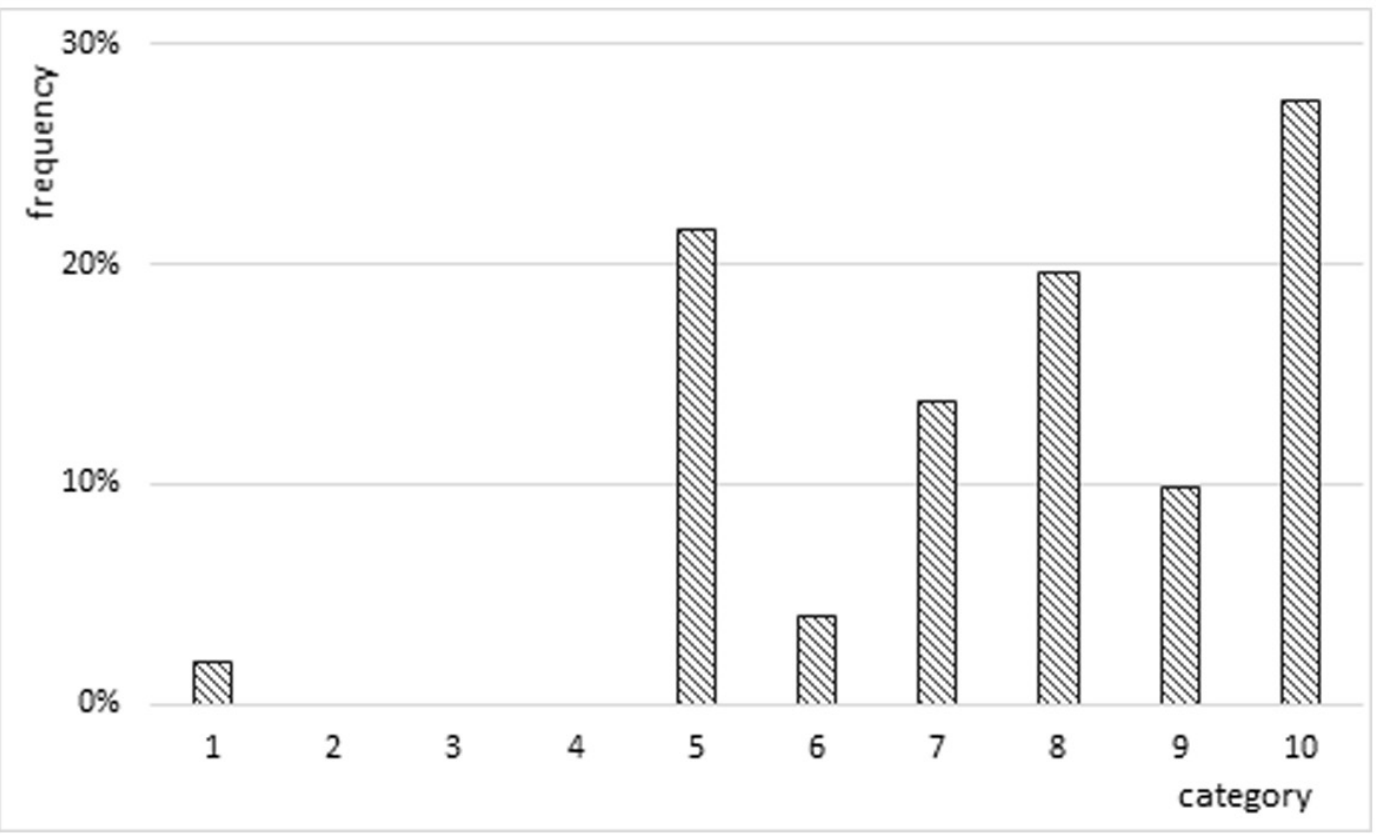

Figure 15. Students' answers to the question "Should the final grades depend on students' individual engagement? (e.g. regular practice on Insta.Ling platform, making online tests, activity during weekly meetings (1 - no, 10 - yes)".

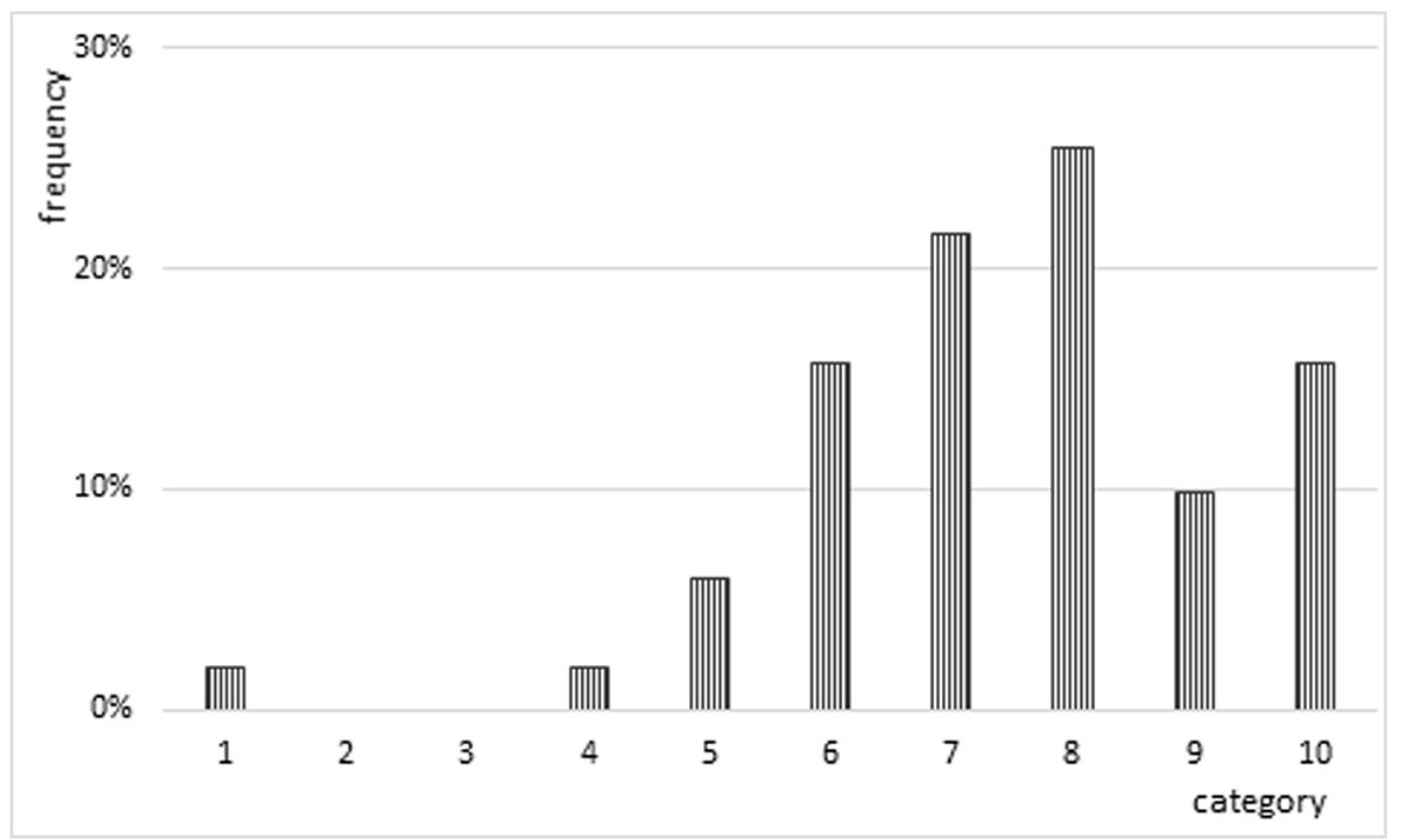

Figure 16. Students answer for the question "Match to what extent did your language competences rise after the course? (1 - strongly disagree, 10 - strongly agree)".

Student 4 "The Insta.Ling platform is really incumbent, and according to me the number of repetitions in a week should be reduced." 
Student 5 "It is too much content (vocabulary) for such a short one term period."

Student 6 "It is too many repetitions that should be done for a positive final grade."

\section{Discussion}

First of all, the Insta.Ling platform is a very helpful tool for teachers, which allows them to assess the students' regular work, the amount of time spent on memorizing vocabulary or details of frequent mistakes made by students. Another benefit is the improvement of students' vocabulary acquisition and the teachers can choose what exact vocabulary will be learnt in the course. If the vocabulary is set in advance, then the students coming into the classroom already know the vocabulary and the teacher can focus on conversations or complex concepts, where the teacher's support is important. What is more, the students' practice is done outside the classroom in a very flexible way. Students can choose the place and time of practice. Another advantage of the platform is the fact, that all students representing the diverse English language level, reach almost equally the same results in the vocabulary test at the end of the course. In other words, students who got better results before the course did not get better results after the course in comparison to students who got lower results at the beginning of the course. The Pearson correlation coefficient was 0,09 (Baranowski, 2018).

This study is one of the first research aiming to establish the effectiveness of the Insta.Ling software, although the Insta.Ling platform is widely used on Polish educational market. According to Insta.Ling administration ${ }^{4}$ there were more than 140 ooo pupils and students working on the platform in first term of academic 2018/2019 year. The success of the Insta.Ling platform can be used to further refine this measure of effectiveness. The present paper is a follow-up of the research begun before at the higher education level (Baranowski, 2018) and in bilingual classes of Lower Secondary School (Baranowski, 2019). This work and author's experience indicate that the tested online tool (Insta.Ling platform) supports the learning and teaching process and is highly effective. The author proposes it might be used in everyday school or university practice.

The one of the final conclusions and analyses show that students (basic level) are able to learn in 13-15 weeks from 300-600 words. The average number of words is 432 . The previous research reveals the similar number 447 (Baranowski, 2018). The number of words memorized during the advanced level course came to 393 in 2016/2017, 267 in 2017/2018 and 216 in 2018/2019. The lower number of words memorized in the advanced level groups can be the result of learning not only the vocabulary but also the content, which mainly was new to students. The basic

4 Information (e-mail) received form Insta.Ling platform administration on $24^{\text {th }}$ January 2019 at the end of the $\mathrm{XI}^{\mathrm{th}}$ programme edition in Poland. 
level course is based on the secondary education terminology (in Biology), so it is well known (in Polish) to all Biology students. This first comparison reveals that the number of words memorized mainly depends on the curriculum but also on individual pace or students' engagement. Previous research in Lower Secondary School confirms that tendency and the number of words memorized in three classes fluctuate from 115 to 148 (Baranowski, 2019). The reason explaining that difference is the Lower Secondary School pupils had to learn not only the vocabulary but also the Biology content which was new to them.

Although, the research did not find the maximum number of repetition which would stop the increase of memorized words, and it seems it could be even higher but then it would require the longer time of regular practice, the number of sessions in a day and/or the number of sentences in one session. It is expected that in the certain pace (the number of regular practice RP) the number of memorized words (given weekly) will not increase. The mechanism of the Insta.Ling platform limits the number of words given to students and they sometimes revise the same vocabulary too often and it makes them rather bored. What is more, the platform is not effective then, and rather similar to traditional drill technique.

What is also clear, that effectiveness of the Insta.Ling platform strongly depends on the regular work and the number of repetitions. This is indicated by Pearson correlation coefficient (PCC - 0.99) and regression $\left(R^{2}-0.98\right)$ in basic level. In advanced level groups the PCC and R results are also significant (in 2016-17, PCC $0.8913 ; \mathrm{R}^{2}-0.7945$, in 2017-18, PCC - 0.8002; $\mathrm{R}^{2}-0.6404$ and in 2018-19, PCC $0.8419 ; \mathrm{R}^{2}-0.7088$.). To measure the statistical significance of the difference (before/ after course) the Student's t-test was used. It brought the results $\mathrm{p}=0.0274$ in general English level and $\mathrm{p}=0.0021$ in the type of the task practised on the platform (sentences with the gaps and the given word in Polish). Previous research (Baranowski, 2018) also confirms that effectiveness ( $\mathrm{p}=1.13 \mathrm{E}-29$ and $\mathrm{p}=2.36 \mathrm{E}-14$ ) but this was based on the number of words memorized (practiced on the platform), what was checked in a test before and after the course. This efficacy was also observed in other foreign languages thanks to online apps such as Duolingo, Rosetta Stone, Busuu, $3 \mathrm{D}$ talking head, (Grego, 2012; Segaran, 2014; Vesselinov, 2009; Vesselinov \& Grego, 2016), so it seems to be a common feature.

Students taking part in a course represent very different and diverse level of English language. And it should be emphasized that regardless of the existing differences in the language level among students, all of them acquire high skills and knowledge. This was also noted in this research. This investigation exposes also a highly positive students' attitude towards the platform. They find it helpful, useful, and recognize it as an effective way of learning English among other apps and methods used during teaching and learning in the course. These findings are also shown in other research and other foreign language learning apps (AlonsoPerez \& Sanchez 2018; Crompton 2013; Munday 2016; Rosell-Aguilar 2016). 
The comparison of the results (and previous study) allow me to assume that Insta. Ling e-learning platform is an effective way to learn new vocabulary and regular practice (RP) positively affects the number of vocabulary memorized. In further research, the experiment based on the control group should be designed and carried out. A very strict control has to be implemented in order to ensure, to what extent participants memorize the number of words thanks to the use of the Insta.Ling platform and how many words they are able to memorize without such a tool using another T\&L method. The future research should overcome the obvious obstacle which is the measurement and monitoring the students' time spent on memorizing vocabulary by themselves at home. Without that, such comparison of the objective effectiveness of Insta.Ling platform is impossible. Although this control might include periodic tests (and other measures) the platform's effectiveness could not be tested. The only solution to that problem is to provide the experiment in primary or secondary education where English classes take part every day. Here such study with experimental and control group could be provided. This would bring the evidence that language skills and number of vocabulary knowledge could rise and differ significantly thanks to Insta.Ling environment in comparison to one of the traditional methods. On the other hand, more statistical power is needed in order to satisfy the preliminary results for all types of courses. A new study should also require more study hours/study time for all participants and the attempt to maximize the number of words memorized in one term. Till now the usefulness of this platform is supported by the number of more than 4000 teachers taking part in the programme.

\section{Bibliography}

Alonso-Perez, R., \& Sanchez, R.A. (2018). Teaching foreign languages through audiovisual translation resources: teachers' perspectives. Applied Language Learning, 28(2), 1-24.

Baller, S., Dutta, S., \& Lanvin, B. (2016). World Economic Forum, The Global Information Technology Report 2016, Geneva.

Baranowski, A. (2018). Skuteczność nauki słownictwa na platformie on-line - instaling.pl. In A. Pytka, M. Maciąg (Eds.). Wiedza i edukacja. Od teorii do praktyki. Lublin: Wydawnictwo naukowe Tygiel.

Baranowski, A. (2019). Skuteczność nauki słownictwa na platformie on-line - instaling.pl w klasach dwujęzycznych gimnazjum. Wydawnictwo Naukowe Tygiel (accepted for publication).

Brown, J.C., \& Park, H.S. (2016). Longitudinal student research competency: Comparing online and traditional face-to-face learning platforms. Advances in Social Work, 17(1), 44-58. 
Cabero-Almenara, J., Marín-Díaz, V., \& Sampedro-Requena, B. (2016). Metaanalysis of research in e-learning published in Spanish journals. International Journal of Educational Technology in Higher Education, 13(25), 1-17.

Crompton, H. (2013). A historical overview of mobile learning: Toward learner centered education. In Z.L. Berge \& L.Y. Muilenburg (Eds.). Handbook of mobile learning. Florence, KY: Routledge.

Cuban, L. (2006). 1:1 laptops transforming classrooms: Yeah, sure. The Teachers College Record. Retrieved from http://vrNW.tcrecord.org/Content.asp?ContentiD=12318.

EU, (2012). European Commission/EACEA/Eurydice, Developing Key Competences at School in Europe: Challenges and Opportunities for Policy 2011/12. Edition Eurydice Report. Luxembourg: Publications Office of the European Union.

EU, (2017). European Commission/EACEA/Eurydice, 2017. Key Data on Teaching Languages at School in Europe - 2017 Edition. Eurydice Report. Luxembourg: Publications Office of the European Union.

Fraillon, J., Ainley, J., Schulz, W., Duckworth, D., \& Friedman, T. (2018). IEA International Computer and Information Literacy Study 2018, Amsterdam, The Netherlands: Assessment Framework.

Haßler, B., Major, L., Warwick, P., Watson, S., Hennessy, S., \& Nicholl, B. (2016). Perspectives on Technology, Resources and Learning: Productive Classroom Practices, Effective Teacher Professional Development. Faculty of Education, University of Cambridge. April 2016. Creative Commons Attribution 4.o. Retrieved from https://creativecommons.org/licenses/by/4.o/

Holcomb, L.B. (2009). Results \& Lessons Learned from 1:1 laptop initiatives: A collective review. TechTrends: Linking Research \& Practice to Improve Learning, 53(6), 49-55.

ITU, (2018). Measuring the Information Society Report. Vol. 1. Geneva, Switzerland: International Telecommunication Union.

Katherine, M., Kimberly, O., Ruzic, R., Horsley, M.K., Franey, J.J., \& Bassett, K. (2016). Teaching in a Digital Age: How Educators Use Technology to Improve Student Learning. Journal of Research on Technology in Education, 48(3), 194-211.

Mothibi, G. (2015). Meta-Analysis of the Relationship between E-Learning and Students' Academic Achievement in Higher Education. Journal of Education and Practice, 6(9), 6-9.

Mumtaz, S. (2000). Factors Affecting Teachers' Use of Information and Communications Technology: a review of the literature. Journal of Information Technology for Teacher Education, 9(3), 319-342.

Munday, P. (2016). The case for using DUOLINGO as part of the language classroom experience. Revista Iberoamericana de Educación a Distancia, 19(1), 83-101.

Noesgaard, S.S., \& Ørngreen, R. (2015). The Effectiveness of E-Learning: An Explorative and Integrative Review of the Definitions, Methodologies and Factors that Promote e-Learning Effectiveness. The Electronic Journal of eLearning, 13(4), 278-290. 
Pai, K. (2013). Assessing Online versus face-to-face learning. "Proceedings", Global Conference on Business and Finance, 8(2), 350.

Penuel, W. (2006). Implementation and effects of one-to-one computing initiatives: A research synthesis. Journal of Research on Technology in Education, 38(3), 329-348.

Petko, D., Cantieni, A., \& Prasse, D. (2017). Perceived Quality of Educational Technology Matters A Secondary Analysis of Students' ICT Use, ICT-Related Attitudes, and PISA 2012. Test Scores. Journal of Educational Computing Research, 54(8), 1070-1091.

Rosell-Aguilar, F. (2016). User evaluation of language learning mobile applications: a case study with learners of Spanish. In A. Palalas, \& M. Ally (Eds.). The International Handbook of Mobile-Assisted Language Learning (pp. 545-581). Beijing: China Central Radio \& TV University Press.

Segaran, K., Zamzuri, A.M.A., \& Hoe, T.W. (2014). Usability and user satisfaction of $3 \mathrm{D}$ talking-head Mobile Assisted Language Learning (MALL) app for non-native speakers. Procedia - Social and Behavioral Sciences, 131, 4-10.

Suhr, K.A., Hernandez, D.A., Grimes, D., \& Warschauer, M. (2010). Laptops and Fourth-Grade Literacy: Assisting the Jump over the Fourth-Grade Slump. Journal of Technology, Learning, and Assessment, 9(5), 5-45.

Vesselinov, R. (2009). Measuring the effectiveness of Rosetta Stone. Final Report. New York: City University of New York Press.

Vesselinov, R., \& Grego, J. (2012). Duolingo effectiveness study. Final Report. New York: City University of New York Press.

Vesselinov, R., \& Grego, J. (2016). The busuu efficacy study. Final Report. New York: City University of New York Press.

Ya Ni, A. (2013). Comparing the Effectiveness of Classroom and Online Learning: Teaching Research Methods. Journal of Public Affairs Education, 19(2), 199-215.

\section{NAUCZANIE JEZZYKA ANGIELSKIEGO Z ZASTOSOWANIEM PLATFORMY INSTA.LING - BADANIA PRZYPADKU NA POZIOMIE SZKOLNICTWA WYŻSZEGO}

Streszczenie: Artykuł przedstawia wyniki badań zastosowania platformy e-learningowej Insta.Ling w nauczaniu języka angielskiego studentów biologii. Celem badań było oszacowanie skuteczności efektywności platformy oraz korelacji pomiędzy liczbą powtórzeń a liczbą nauczonych słów. Całkowita liczba studentów włączonych w badania wyniosła 129, z 6 grup, wśród trzech roczników akademickich na Uniwersytecie Kardynała Stefana Wyszyńskiego w Warszawie. Wyniki te pozwalają przypuszczać, iż platforma Insta.Ling jest efektywnym narzędziem do nauki słownictwa, a systematyczne powtórzenia wymiernie wpływają na zapamiętanie wyrazów. 
Słowa kluczowe: e-learning; technologia informacyjno-komunikacyjna (TIK); wirtualna platforma e-learningowa; szkolnictwo wyższe; nauczanie języka angielskiego.

Artur Baranowski - doktor nauk biologicznych (UMK 2006) i magister filologii angielskiej (WSEH 2009). Asystent na Wydziale Biologii i Nauk o Środowisku Uniwersytetu Kardynała Stefana Wyszyńskiego w Warszawie od 2009 roku. Koordynator wielu wydziałowych wydarzeń popularyzujących naukę w ramach m.in. Noc Biologów, Dzień Ziemi, Piknik Naukowy, Festiwale Nauki oraz wielu lekcji otwartych, warsztatów i laboratoriów dla wszystkich typów szkół. Trener Centrum Edukacji Obywatelskiej (2015). Ponadto nauczyciel dyplomowany, przedmioty nauczane to biologia po angielsku, biologia, język angielski. Autor i współautor wielu projektów eTwinning (Krajowa Odznaka Jakości 2017, Europejska Odznaka Jakości 2018) oraz Comenius i Erasmus+. Laureat konkursu EDU Inspiracje (2013) w programie Wizyty Studyjnej dla instytucji oraz nominowany w konkursie EDU Inspirator (2015) organizowanych przez Fundację Rozwoju Systemu Edukacji. Odznaczony Brązowym Krzyżem Zasługi, Medalem Komisji Edukacji Narodowej, Nagrodą Ministra Edukacji. Autor i współautor wielu publikacji i wystąpień konferencyjnych o tematyce nauczania i uczenia się z wykorzystaniem cyfrowych technologii. Adres e-mailowy: a.baranowski@uksw.edu.pl 